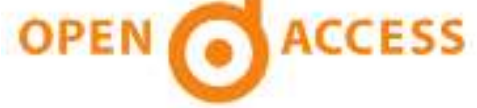

\section{International Journal of Applied Sciences and Biotechnology}

\author{
A Rapid Publishing Journal
}

ISSN 2091-2609

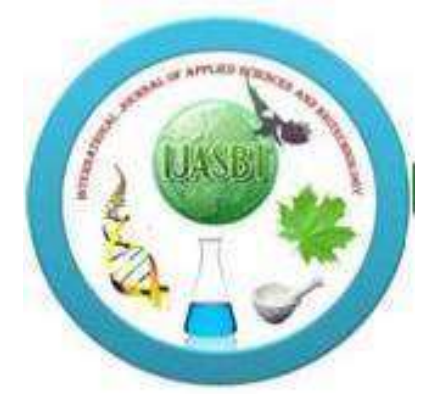

\section{Available online at:}

$\frac{\text { http://www.ijasbt.org }}{\&}$

http://www.nepjol.info/index.php/IJASBT/index

\section{Indexing and Abstracting}

CrossRef, Google Scholar, Global Impact Factor, Genamics, Index Copernicus, Directory of Open Access Journals, WorldCat, Electronic Journals Library (EZB), Universitätsbibliothek Leipzig, Hamburg University, UTS (University of Technology, Sydney): Library, International Society of Universal Research in Sciences (EyeSource), Journal Seeker, WZB, Socolar, BioRes, Indian Science, Jadoun Science, Jour-Informatics, Journal Directory, JournalTOCs, Academic Journals Database, Journal Quality Evaluation Report, PDOAJ, Science Central, Journal Impact Factor, NewJour, Open Science Directory, Directory of Research Journals Indexing, Open Access Library, International Impact Factor Services, SciSeek, Cabell's Directories, Scientific Indexing Services, CiteFactor, UniSA Library, InfoBase Index, Infomine, Getinfo, Open Academic Journals Index, HINARI, etc.

\section{CODEN (Chemical Abstract Services, USA): IJASKD}

Vol-2(3) September, 2014
Impact factor*: $\mathbf{1 . 4 2 2}$

Scientific Journal Impact factor ${ }^{\#}$ : 3.419 IC Value: 4.37 


\title{
WEEDS AND THEIR EFFECT ON THE PERFORMANCE OF MAIZE AND FINGER MILLET IN MID- HILLS OF NEPAL
}

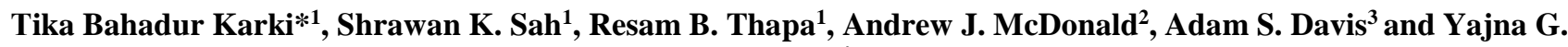 \\ Khadka $^{4}$ \\ ${ }^{1}$ Institute of Agriculture and Animal Sciences, Rampur, Nepa \\ ${ }^{2}$ CIMMYT, South Asia Regional Office, Nepal \\ ${ }^{3}$ United States Departments of Agriculture/ Agricultural Research Service, Urbana, Illinois, USA \\ ${ }^{4}$ Nepal Agricultural Research Council, Nepal \\ *Corresponding author email: tbkarki2003@gmail.com
}

\begin{abstract}
Relay cropping of maize with fingermillet (maize/fingermillet) is the predominant cropping system for sustaining food security situation in the hilly regions of Nepal. In this region weed pressure severely reduces crop yields. Basic information on weed species composition, biomass production and their effect on crop yields and economics are lacking for this region. This information will be necessary to develop effective weed management strategies for the future. In light of this an empirical study was carried out in two representatives mid hill districts of Parbat and Baglung during summer season of 2010/2011 in Nepal. A total of 10 major weed species with densities of 172 in Parbat and 311 per $0.25 \mathrm{~m}^{2}$ area in Baglung were observed. The highest percentage of both relative and absolute densities were recorded for Ageratum conyzoides in Parbat and Polygonum chinensis in Baglung. Weed infestation under farmers practice of crop management reduced the grain yield of maize by $1.985 \mathrm{Mt} \mathrm{ha}^{-1}(117 \%)$ in Baglung and $1.760 \mathrm{Mt} \mathrm{ha}^{-1}(108 \%)$ in Parbat. Similarly, in finger millet it was $0.489 \mathrm{Mt} \mathrm{ha}^{-1}(63 \%)$ in Baglung and $0.403 \mathrm{Mt} \mathrm{ha}^{-1}$ in Parbat. Similarly, the combined yield of both the crops was also significantly reduced by $79.3 \%$ and $61.7 \%$ in Baglung and Parbat respectively. Hence, weeds are directly affecting the crop performance in the region. Therefore, there is an urgent need to develop an alternative crop production system in the hills.
\end{abstract}

Keywords: Maize/finger-millet, hills, weeds, index, grain yield

\section{Introduction}

Maize (Zea mays L.) and finger millet (Eleusine coracana Gaertin.) are the second and fourth most widely produced cereal crops in Nepal, respectively, with over $70 \%$ of maize and $75 \%$ of fingermillet being produced in the mid-hill regions. Of the total area under fingermillet cultivation, $85 \%$ is relayed with maize in Nepal. Maize-millet systems are advantageous to farmers becasue of reduced land preparation and more efficient utilization of moisture, nutrient, and labour resources (Subedi, 2001). Yet low productivity of maize-millet systems (average yields of 2.5 $\mathrm{Mtha}^{-1}$ for maize and 1.13 $\mathrm{Mtha}^{-1}$ for finger-millet (ABPSD, 2012). is hindering food security in the mid-hills. Weed infestation is one of the major factors that contribute to low system productivity in the hills. However, information on the major weed species and their effects on yield penalties are meager for maize-millet systems in the hills. Therefore, the present investigation was carried-out to identify the major weed species and determine to what extent the weed infestation affect this system's yield in the mid-hills of Nepal.

\section{Materials and Methods}

Study site

The study was carried out at Pang village in Parbat and Langgaun in Baglung district in the western hill region of Nepal. The prevailing cropping system of the region was maize/fingermillet during the rainy season and wheat/ rapeseed mustard or fallow in winter. Soils of both locations were reddish-brown in color, clay-loam in texture and had a pH of 6.0 to 6.5 in Lunggaun and 6.0 in Pang. Total soil NPK was $0.18 \%, 71 \mathrm{ppm}$ and $111 \mathrm{mg} \mathrm{kg}^{-1}$ in Lunggaun, and $0.21 \%, 65$ ppm and $95 \mathrm{mg} \mathrm{kg}^{-1}$ in Pang. Soil organic carbon at both locations was 1.6 percent. The highest rainfall was recorded during the month of July and June (1677 and 1558 $\mathrm{mm}$, respectively). November and January received no rainfall. Average maximum and minimum temperatures of the region were 22.39 and $12.11^{\circ} \mathrm{C}$ during the survey year.

\section{Experimental set up}

Maize was planted at both sites during the second week of April, 2010. Fingermillet was relay planted in standing maize 55 days after maize seeding. The crop was manured with ten tons of farm yard manure (fresh weight) per hectare 
during land preparation and 40 kilograms of urea $(46 \% \mathrm{~N})$ per hectare was applied as top dressing during knee high stage of the crop. All crops were maintained under rainfed conditions without irrigation.

Two weed management treatments representing conventional farmers' practice (FP) of weed management and weed free (WF) were implemented in the field of ten farmers, 5 from each villages. Farmers managed all other field operations according to their usual practice The FP vs. WF comparison was carried out on five farmer's fields in both Pang and Lunggaun. Every field contained four plots each of both FPP and RPP treatments running parallel in strips. Quadrats were of $5 \mathrm{~m} \times 5 \mathrm{~m}\left(25 \mathrm{~m}^{2}\right)$. In the FP plots farmers carried out three cultivations, the first at 30-40 days after seeding, the second at earthing up operation (inter-row cultivation) and the third at finger millet transplanting time. Cultivations were conducted using a small locally-made iron hoe. Weed free plots were likewise treated with three cultivations as stated above, but in addition weeds were pulled out immediately after the emergence by hand on a regular interval of seven days basis.

\section{Observations recorded}

In order to record the dominant weed species and work-out thier relative density, absolute density, relative frequency and absolute frequency under maize-based systems, 4 quadrats measuring $0.5 \times 0.5 \mathrm{~m}^{2}$ were placed in each farmer's field for all fiveat both locations. Weed species, densities and biomass (dry weight) data were estimated from quadrats during the inter-row cultivation (earthing-up operation) at 75 days after seeding (DAS) of maize. The second observation was done at physiological maturity of the crop. Weeds inside the quadrats were counted, classified and the biomass recorded in grams per unit area. For this, the weeds inside each quadrat were harvested, recorded and then oven dried for 48 hours at $70^{\circ} \mathrm{C}$. Average dry weight was calculated and then converted into $\mathrm{m}^{-2}$.Various weed indices were calculated as shown below:

$$
\text { Relative population density }(\mathrm{RD})(\%)=\frac{\text { Absolute density for a given species }}{\text { Total absolute density for all species }}
$$

Absolute population density $=$ Total no. of individuals of a species in all quadrates

Total number of quadrates

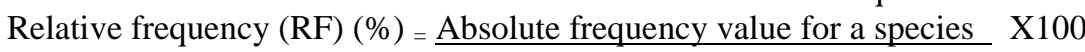

Total absolute frequency values for all species

Absolute frequency $(\%)=\underline{\text { Number of quadrates in which species occurs }} \times 100$

Total number of quadrates

Table 1. Weeds and population in a $0.25 \mathrm{~m}^{2}$ area during rainy season under maize based cropping system in Pang, Parbat

\begin{tabular}{lllllllllllll}
\hline $\begin{array}{l}\text { Quadrat } \\
\text { No }\end{array}$ & W1 & W2 & W3 & W4 & W5 & W6 & W7 & W8 & W9 & W10 & Total \\
\hline 1 & 7 & 2 & 3 & 4 & 0 & 2 & 13 & 0 & 0 & 0 & 31 \\
2 & 13 & 9 & 4 & 3 & 2 & 1 & 9 & 0 & 2 & 0 & 43 \\
3 & 7 & 8 & 5 & 4 & 0 & 2 & 12 & 0 & 1 & 0 & 39 \\
4 & 7 & 3 & 2 & 2 & 0 & 2 & 9 & 0 & 0 & 0 & 25 \\
5 & 9 & 2 & 3 & 2 & 0 & 0 & 11 & 0 & 7 & 0 & 34 \\
\hline Species & 43 & 24 & 17 & 15 & 2 & 7 & 54 & 0 & 10 & 0 & 172 \\
total & & & & & & & & & & & &
\end{tabular}

total name of weed species are mentioned in table 3

Table 2. Weeds and population in a $0.25 \mathrm{~m} 2$ area during rainy season under maize based cropping system in Lungaun, Baglung

\begin{tabular}{|c|c|c|c|c|c|c|c|c|c|c|c|}
\hline 1 & 19 & 12 & 1 & 9 & 2 & 8 & 2 & 4 & 2 & 4 & 63 \\
\hline 2 & 4 & 11 & 3 & 11 & 0 & 11 & 1 & 7 & 2 & 5 & 55 \\
\hline 3 & 3 & 7 & 2 & 7 & 2 & 13 & 0 & 3 & 9 & 1 & 47 \\
\hline 4 & 4 & 17 & 0 & 4 & 1 & 2 & 2 & 11 & 4 & 14 & 59 \\
\hline 5 & 16 & 13 & 0 & 3 & 7 & 20 & 0 & 12 & 7 & 9 & 87 \\
\hline Species & 46 & 60 & 6 & 34 & 12 & 54 & 5 & 37 & 24 & 33 & 311 \\
\hline
\end{tabular}

\begin{tabular}{lllllllllll}
\hline Quadrat & W1 & W2 & W3 & W4 & W5 & W6 & W7 & W8 & W9 & W10
\end{tabular}

total

Note: name of weed species are mentioned in table 3

Table 3. Major weed species under maize based cropping system

\begin{tabular}{lll}
\hline Weed species No & Nepali name & Scientific name \\
\hline W1 & Abhijalo & Drymaria cordata \\
W2 & Ratnaulo & Plolygonum chinensis \\
W3 & Kodejhar & Dactyloctenium aegypticum \\
W4 & Banso & Echinochloa colonum \\
W5 & Mothe & Cyperus rotundus \\
W6 & Kanejhar & Commelina spp \\
W7 & Gandhe & Ageratum conyzoides \\
W8 & Chariamilo & Oxalis spp \\
W9 & Dubo & Cynodon dactylon \\
W10 & Siru & Imperata cylindrica \\
\hline
\end{tabular}


Analysis of variance for yield parameters of maize and fingermillet was done with GENSTATC Discovery version. Treatments were compared using the "F-test" and any significant differences between treatments were compared by Least Significant Difference (LSD) at 5\% level of probability.

\section{Results and Discussion}

\section{Major weeds and densities}

Variation in density among the weed species was found to be significant in both Parbat and Baglung. Almost all weed species were common in both the sites except Imperata cylindrica and Oxalis spp were not found in Baglung. Weed density of Drymaria cordata and Cynodon dactylon did not vary among sites. However, higher densities were recorded in Polygonum chinensis, Echonochloa colonum, Commelina spp in Parbat as against Baglung. Where as, only one species Ageratum conyzoides was recorded to be the highest in density in Baglung compared with Parbat (Table 1, 2 and 3). Similar weed species were also observed and reported in Lumle (1600 m.asl) in Kaski (Karki et a 2010).

\section{Weed indexes}

In Parbat : The highest Relative Density (RD\%) or Community Abundance (CA\%) was observed in Ageratum conyzoides (W7) with 31.40 followed by 15 in Drymaria cordata (W1) and 13.95 in Polygonum chinensis (W2) and 9.88 in Dactyloctenium aegypticum (W3) (Table 4).

Similarly, the Absolute Density (AD) was also observed as 10.8, 8.6, 4.8 and 3.4 in Ageratum conyzoides (W7), Drymaria cordata (W1), 13.95 in Polygonum chinensis (W2) and 9.88 in Dactyloctenium aegypticum (W3) respectively(Table 4).

Absolute frequency (AF\%) of 14.71 was recorded in Drymaria cordata (W1), Polygonum chinensis (W2) and Dactyloctenium aegypticum (W3) with the lowest value of 0 in Ageratum conyzoides (W7), Cynodon dactylon (W9) and Imperata cylindrica (W10) (Table 4).
In Baglung: The highest Relative Density ( $\mathrm{RD} \%)$ or Community Abundance (CA\%) was found in Polygonum chinensis (W2) with 19.29 followed by Commelina spp (W6) with 17.36, Oxalis spp (W8) with 11.90, Echinochloa colonum (W4) with 10.93 and Imperata cylindrica (W10) with 10.61. The lowest value of 1.61 was recorded in Ageratum conyzoides (W7) (Table 4).

Absolute Density (AD) was the highest in Polygonum chinensis (W2) with 12.0 followed by Echinochloa colonum (W4) with 10.8, Drymaria cordata (W1) with 9.2 and Oxalis spp (W8) with 7.4 having the lowest of value 1 in Ageratum conyzoides (W7) (Table 4).

Absolute Frequency (AF\%) value of 11.11 was recorded in Drymaria cordata (W1), Polygonum chinensis (W2), Echinochloa colonum (W4), Commelina spp (W6), Oxalis spp (W8), Cynodon dactylon (W9) and Imperata cylindrica (W10) (Table 4). However, the lowest value of AF (6.67 \% ) was recorded in Ageratum conyzoides (W7) and Dactyloctenium aegypticum (W3) (Table 4).

\section{Effect of weed on grain yield of maize and fingermillet}

Irrespective of location, significantly higher grain yields were recorded for maize under weeds free treamtments than in farmer's practice of weed management treatments. However, the fertility status of the field plots were not evaluated, hence the grain yield might be affected accordingly.

It is also interesting to note that in Baglung, although WF plots showed higher grain yield than FP plots, they also showed higher a higher level of variation. This might be attributed to variations in the composition of weed species, initial densities, or ground cover of weeds. The findings were also in accordance with the findings of Knezevic et al (2002) .

In Parbat, the variation in grain yields of both the crops was observed to be narrow (Table 5). The reduction in grain yield due to weeds may be attributed to several factors like weed-crop competition for moisture, nutrient and light (Hussain et al 2008).

Table 4. Relative and absolute densities, relative and absolute frequencies of major weed species across the survey districts

\begin{tabular}{llllllllllll}
\hline Particular & W1 & W2 & W3 & W4 & W5 & W6 & W7 & W8 & W9 & W10 & Total \\
\hline Pang, Parbat & & & & & & & & & & & \\
RD(\%) & 25 & 14.0 & 9.9 & 8.7 & 1.2 & 4.1 & 31.4 & 0 & 5.8 & 0 & 100 \\
AD & 8.6 & 4.8 & 3.4 & 3 & 0.4 & 1.8 & 10.8 & 0 & 2 & 0 & 34 \\
AF (\%) 14.71 & 14.7 & 14.7 & 5.8 & 11.8 & 14.7 & 0 & 8.8 & 0 & 0 & 100 & \\
\hline \multicolumn{2}{l}{ Lunggaun, Baglung } & & & & & & & & & & \\
RD (\%) & 14.8 & 19.3 & 1.9 & 10.9 & 3.9 & 17.4 & 1.6 & 11.9 & 7.7 & 10.6 & 100 \\
AD & 9.2 & 12 & 1.2 & 6.8 & 2.4 & 10.8 & 1 & 7.4 & 4.8 & 6.6 & 62.2 \\
AF (\%) 11.1 & 11.1 & 6.7 & 11.1 & 8.9 & 11.1 & 6.7 & 11.1 & 11.1 & 11.1 & 100 & \\
\hline
\end{tabular}

Note: name of weed species are mentioned in table 3 
Table 5. Grain yield of maize and fingermillet as affected by weed management practices in Baglung and Parbat, 2010.

\begin{tabular}{|c|c|c|c|}
\hline \multirow{2}{*}{ Location/practice } & \multicolumn{3}{|c|}{ Grain yield $\left(\mathrm{Mt} \mathrm{ha}^{-1}\right)$} \\
\hline & Maize & Fingermillet & Combined \\
\hline \multicolumn{4}{|l|}{ Baglung } \\
\hline Farmers practice & 1.683 & 0.776 & 2.601 \\
\hline Weed free & 3.668 & 1.265 & 4.666 \\
\hline Yield gain $\left(\mathrm{Mt} \mathrm{ha}^{-1}\right)$ & $1.985(117)$ & $0.489(63)$ & $2.064(79.3)$ \\
\hline \multicolumn{4}{|l|}{ Parbat } \\
\hline Farmers practice & 1.628 & 0.829 & 2.751 \\
\hline Weed free & 3.388 & 1.231 & 4.450 \\
\hline Yield gain (Mt ha-1) & $1.760(108.1)$ & $0.403(48.6)$ & $1.699(61.7)$ \\
\hline Grand mean & 2.595 & 1.025 & 3.617 \\
\hline $\mathrm{LSD}_{0.05}$ & 0.225 & 0.106 & 0.312 \\
\hline $\mathrm{CV}, \%$ & 8.6 & 10.2 & 8.5 \\
\hline
\end{tabular}

Note: figures in the parentheses are percentage increase in yield

\section{Conclusion}

Altogether 10 weed species were found in common in maize field for both districts during 2009. Among them, grasses were the dominant. The highest percentage of both relative and absolute densities were recorded for Ageratum conyzoides in Parbat and Polygonum chinensis in Baglung. The higher absolute frequency percentage was recorded in Drymaria cordata, Polygonum chinensis and Dactyloctenium aegypticum with the lowest value of 0 in Ageratum conyzoides, Cynodon dactylon and Imperata cylindricain Parbat. Similarly, in Baglung, the absolute frequency was recorded higher in Drymaria cordata, Polygonum chinensis, Echinochloa colonum), Commelina spp, Oxalis spp, Cynodon dactylon and Imperata cylindrica with the lower value was recorded in Ageratum conyzoides and Dactyloctenium aegypticum. Grain yield of maize under weed free conditions were $2.5 \mathrm{Mt} \mathrm{ha}^{-1}$ in Parbat and 2.7 $\mathrm{Mt} \mathrm{ha}^{-1}$ in Baglung, whereas in farmer's practice of weed management it was 1.6 $\mathrm{Mt} \mathrm{ha}^{-1}$ in Parbat and 1.7 $\mathrm{Mt} \mathrm{ha}^{-1}$ in Baglung. Similarly, the grain yield of fingermillet losses due to weed infestation were up to $47.2 \%$, when the maize field kept un-weeded throughout the first growing season.

\section{Acknowledgement}

Karki received grant-aided support of his doctoral thesis research from the International Maize and Wheat Improvement Centre (CIMMYT). The authors are thankful to the entire research team of Regional Agricultural Research Station, Lumle. We are grateful to the collaborating farmers from the research command area of Lumle. We are also thankful to John Laborde, graduate student from University of Nebraska, USA for his help in manuscript preparation.

\section{References}

ABPSD (2012) Agri-Business Promotion and Statistics Division. Ministry of Agriculture and Co-operatives, Government of Nepal, Kathmandu, (2012)

Hussein FA, El-Metawally IM and El-Desok ER (2008) Effect of plant spacing and weed control treatments on maize yield and associated weeds in sandy soils. American-Eurassian J. Agric \& Environ. Sci. 4 (1)

Karki TB, S B B K and Mishra RC (2010) Critical period of weed control in maize. Nepalese Journal of Agricultural Sciences, 8: 39-47.

Knezevic SZ, Evans SP, Blankenship EE, VanAckerand RC and Lindquist JL (2002) Critical period for weed control: the concept and data analysis. Weed Science. 50: 773-786. DOI: $\underline{10.1614 / 0043-}$

\section{5(2002)050[0773:CPFWCT]2.0.CO;2}

Subedi K D (2001) Maize and finger millet relay intercropping system in the hills of Nepal: Issues for sustainability. Sustainable Maize Production Systems for Nepal. Proceedings of Maize Symposium. 3-4 December, 2001, Kathmandu, Nepal, (2001). 